\title{
Cardiovascular Effects of Neuropeptide Y
}

\author{
Bernard Waeber, Jean-François Aubert, Roger Corder, Dominique Evéquoz, Jürg Nussberger, \\ Rolf Gaillard, and Hans R. Brunner
}

Neuropeptide $Y$ (NPY) is present in the brain, the adrenal medulla, and peripheral sympathetic nerves. This peptide is released together with catecholamines during sympathoadrenal activation. It possesses direct vasoconstrictor properties that are not dependent on simultaneous adrenergic activation. Moreover, it potentiates the vascular effect of several stimulatory substances and may contribute to the modulation of blood pressure respon-siveness under a number of circumstances. NPY may also be indirectly involved in the control of blood pressure through regulating the release of hormones with well-established actions on the cardiovascular system. Am J Hypertens 1988;1:193-199

KEY wORDS: Neuropeptide $Y$, sympathetic nervous system, catecholamines, renin-angiotensin system, blood pressure

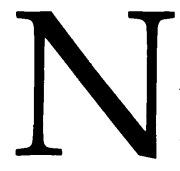

europeptide $Y$ (NPY) is a 36 amino acid peptide first isolated from porcine brain. ${ }^{1,2}$ It has been found to be widely distributed throughout the central and peripheral nervous system of a variety of mammals including man (for review see references $3-6$ ). This peptide is co-stored with norepinephrine in perivascular nerve fibers. It has also been localized to the adrenal medulla. NPY has been shown to induce vasoconstriction through a direct effect. In addition, it has been recognized to potentiate the contractile response evoked by stimulation of $\alpha$ adrenoceptors.

The vasoactive properties of NPY have been extensively studied during the last few years. In the present work, we intend to focus on the evidence suggesting a role for this newly discovered peptide in the regulation of vascular tone.

\section{CARDIOVASCULAR EFFECTS OF NPY}

Central Effects Several observations support the view that NPY may actively participate in the central control of blood pressure. It is present in catecholamine-con-

From the Division of Hypertension, Centre Hospitalier Universitaire Vaudois, Lausanne (BW, J-FA, DE, JN, HRB), and (RC, RG) Clinique Médicale, Hôpital Cantonal Universitaire, Geneva.

This work was supported by grants from the Cardiovascular Research Foundation and the Swiss National Science Foundation.

Address correspondence and reprint requests to Bernard Waeber, MD, Division of Hypertension, CHUV, 1011 Lausanne, Switzerland. taining neurons located in areas physiologically involved in the regulation of the cardiovascular system, particularly at the level of the nucleus tractus solitarius. ${ }^{7,8}$ One group of investigators has shown that intraventricular administration of NPY causes in conscious as well as in anesthetized rats a hypotension accompanied by a bradycardia., ${ }^{9,10}$ This type of hemodynamic response corresponds to what is expected to occur after central injection of $\alpha_{2}$-adrenergic agonists. It is therefore of interest that brain $\alpha_{2}$-adrenergic binding sites have been reported to increase in the presence of NPY. ${ }^{11}$ It has been suggested that NPY stimulates presynaptic receptors on norepinephrine and/or epinephrine nerve terminals, which may enhance the presynaptic $\alpha_{2}$-adrenoceptor function to inhibit norepinephrine release. ${ }^{12}$ The hypotension and bradycardia induced by intracisternal and intraventricular administration of NPY has however not been observed by all investigators. ${ }^{13,14}$ NPY may even be responsible in rats for a dose-dependent pressor response and a tachycardia. ${ }^{14}$ Such effects could be prevented by pretreating intravenously with $\alpha$-and $\beta$-adrenoceptor blocking agents, suggesting that the cardiovascular response to centrally administered NPY is mediated by an activation of the sympathetic nervous system. Microinjection of NPY at a large dose into the nucleus tractus solitarius of rats decreases blood pressure and heart rate, whereas a pressor response can be obtained when a large dose is used. ${ }^{15} \mathrm{It}$ is of note that a functional interaction between NPY and 
norepinephrine seems to exist at the central level, NPY potentiating the effect of the catecholamine. ${ }^{15}$ Furthermore, NPY seems to contribute to the regulation of central catecholamine turnover ${ }^{16}$ and to exert a negative feedback inhibitory effect on norepinephrine release at the presynaptic level. ${ }^{17}$ Whether the level of NPY in the brain is relevant to the development of some experimental forms of hypertension remains unclear. Strain- and age-related differences in NPY immunoreactivity occur in normotensive and genetically hypertensive rats. ${ }^{18,19}$ Concerning the mechanism of action of NPY at the cellular level, little was known until the recent report of a NPY-induced inhibition of adenylate cyclase activity ${ }^{20,21}$ it is not yet known however if this action is common to all the reported effects of NPY.

\section{Peripheral Actions}

Vascular Distribution NPY has been identified by radioimmunochemical and immunocytochemical methods in perivascular nerve fibers of various organs, for instance at the level of cerebral, renal, coronary, mesenteric, and femoral arteries. ${ }^{3-6}$ NPY-containing nerve terminals are present with a much higher frequency around arteries than around veins..$^{22}$ Most of the NPY-containing neurons are probably catecholaminergic, as it is possible to reduce the NPY content of perivascular nerve endings by performing either surgical or chemical sympathectomy. ${ }^{23-25}$

Effects of NPY in Isolated Vascular Preparations NPY possesses vasoconstrictor properties in isolated segments of arteries. ${ }^{26-29}$ The NPY-evoked contraction of vascular smooth muscle cells is not dependent on adrenergic mechanisms, as it cannot be antagonized by $\alpha$ adrenoceptor blockade. ${ }^{30,31}$ However, an important vascular action of NPY appears to be the potentiation of the contractile response to norepinephrine ${ }^{26,28,32,33}$ and indeed to nerve stimulation. ${ }^{29,33}$ The NPY-mediated enhancement of vascular contraction is not limited to norepinephrine. The same effect has been observed with histamine ${ }^{26,32}$ but the effect of NPY on the response to 5-hydroxytryptamine and $\mathrm{K}^{+}$requires clarification. ${ }^{26,33}$ The fact that the potentiating effect of NPY can be observed with different vasoconstrictors suggests a number of NPY-induced effects beyond the receptor of the vascular smooth muscle cell. However, NPY leads to a depolarization of the musculature of the rat tail artery, ${ }^{33}$ and this effect may account to some extent for the potentiating action. By depolarizing the arterial smooth muscle it is indeed possible to increase the contractile responses to a variety of constrictor agonists. ${ }^{34,35}$ The entry of $\mathrm{Ca}^{2+}$ into the vascular smooth muscle cells seems to be important, although not absolutely necessary, for attainment of the direct constrictor effect of NPY. ${ }^{31}$ The potentiation of norepinephrine-induced vasoconstriction depends probably more on the $\mathrm{Na}^{+}$ than the $\mathrm{Ca}^{2+}$ influx. ${ }^{28}$ For this latter effect, an intracellular sequestered $\mathrm{Ca}^{2+}$ pool appears to play a key role. ${ }^{28}$ It is relevant in this context that evidence for a NPY-induced inhibition of adenylate cyclase activity has also been found in blood vessels. ${ }^{36}$ Recently, it has also been suggested that NPY modulates adrenergic neurotransmission by an endothelium-dependent mechanism. ${ }^{37}$ Finally, it has to be stressed that the degree to which preand postjunctional effects of NPY are concerned in the process of sympathetic neurotransmission is still unclear. There is however good indication to suggest that the postjunctional contractile and facilitatory mechanisms prevail upon the prejunctional inhibitory action on norepinephrine release. ${ }^{38}$

Effects of NPY in the Isolated Blood-Perfused Spleen NPY-like immunoreactivity has been detected within the adrenergic innervation of spleen tissue ${ }^{39,40}$ Interestingly, the splenic vascular bed, unlike many isolated vessels, ${ }^{26}$ is very sensitive to the direct vasoconstrictor action of NPY. ${ }^{41}$ Moreover, NPY is released into the venous drainage by sympathetic nerve stimulation. ${ }^{42}$ The increase in splenic arterial perfusion pressure evoked by electrical stimulation cannot be prevented by adrenoceptor antagonists at doses sufficient to abolish the response to norepinephrine.

Effects of NPY in the Isolated Heart and Cultured Atrial Cells The presence of NPY has been demonstrated in nerve fibers surrounding blood vessels and myocytes. ${ }^{22,43}$ In the isolated rabbit heart, NPY has been reported to reduce myocardial perfusion together with the force of contraction. ${ }^{44,45}$ Other studies failed however to detect a direct action of NPY on the heart muscle. ${ }^{46,47}$ The most striking cardiac effects of NPY observed using in vitro preparations appear to be a prejunctional suppression of stimulated norepinephrine release $e^{47}$ and a contraction of the coronary vascular bed. ${ }^{46,48}$ The constrictor effect of NPY is not affected by $\alpha$-adrenoceptor blockade but is likely to depend on extracellular calcium ions. ${ }^{48} \mathrm{~A}$ new insight in the mode of action of NPY has emerged recently from studies performed on primary cultures of rat heart atria. ${ }^{49} \mathrm{NPY}$ was found to inhibit the stimulation of adenylate cyclase activity known to occur during activation of $\beta$-adrenoceptors. Pretreatment of the cells with pertussis toxin prevented this inhibitory effect. This observation suggests that NPY binds to its receptor at the surface of the cell to activate an inhibitory membrane protein called $\mathrm{Gi}$, which then turns off the cyclic AMP pathway.

NPY and the Adrenal Medulla The presence of NPY has been established in adrenal medullary cells $\mathrm{s}^{50-53}$ and adrenal medullary pheochromocytoma tissue. ${ }^{52,54-57} \mathrm{In}$ terestingly, the content of NPY in the tumors is generally increased in comparison with normal adrenals. Some pheochromocytoma appear to synthetize and se- 
crete enough of this peptide to raise circulating NPY levels. ${ }^{54,56,57}$ Whether determination of plasma NPY levels is of practical use in the diagnosis of pheochromocytoma needs to be further explored..$^{57}$ It remains also a matter of speculation whether the elevation of plasma NPY levels found in some patients with pheochromocytoma is sufficient to contribute to the hypertensive state.

A key question is whether NPY is released into the circulation upon sympathetic activation. This seems to be really the case since both reflex sympathetic activation and electrical nerve stimulation of the adrenal have been shown recently to cause a marked increase in NPY and catecholamine output. ${ }^{58}$ In the intact animal, however, there is evidence suggesting that the sympathetic nerves contribute to the largest extent to the increase in plasma NPY concentrations after activation of the sympathoadrenal system. ${ }^{59}$ In basal conditions, conscious normotensive rats exhibit similar circulating levels of NPY independently of the presence or the absence of adrenal medulla (personal observation).

Effects of NPY in Intact Animals In pithed rats, NPY infusion in a dose that does not affect blood pressure per se enhances the pressor response to $\alpha_{1}$-adrenoceptor stimulation with phenylephrine as well as to electrical stimulation of the sympathetic outflow..$^{60}$ In these rats, a direct pressor effect of NPY can be obtained by raising the dose of the peptide. ${ }^{60}$ Potentiation of the blood pressure effect of $\alpha$-adrenoceptor stimulation has also been observed in conscious rats infused with a nonpressor dose of NPY. ${ }^{61}$ This was shown utilizing not only norepinephrine, but also the indirectly acting sympathomimetic agent tyramine (personal observation). Interestingly, the blood pressure response to angiotensin II was also clearly increased by this low dose of NPY which given alone was devoid of pressor effects. In contrast, NPY did not alter the response to vasopressin. Several studies have confirmed that the NPY-induced pressor effect is not attenuated by $\alpha$-adrenoceptor blockade. ${ }^{60-64}$

The vasoconstrictor activity of NPY in vivo seems to be $\mathrm{Ca}^{2+}$-dependent, as it can be reduced by calcium entry blockade. ${ }^{60,62,64} \mathrm{It}$ is possible to trigger the release of NPY into systemic circulation by splanchnic nerve stimulation. ${ }^{65}$ Evidence has been provided from studies in pithed guinea pigs that clonidine, an $\alpha_{2}$-adrenoceptor agonist, reduces the increase in plasma NPY concentration resulting from electrical nerve stimulation. ${ }^{66}$ This points to a role of presynaptic $\alpha_{2}$-adrenoceptors in the modulation of NPY release by nerve terminals. The importance of sympathetic outflow in determining circulating levels of NPY is strongly suggested by the fact that the ganglion blocker pentolinium, at the same time as reducing blood pressure, markedly reduces in acute experiments the peptide concentration in the plasma. ${ }^{67}$

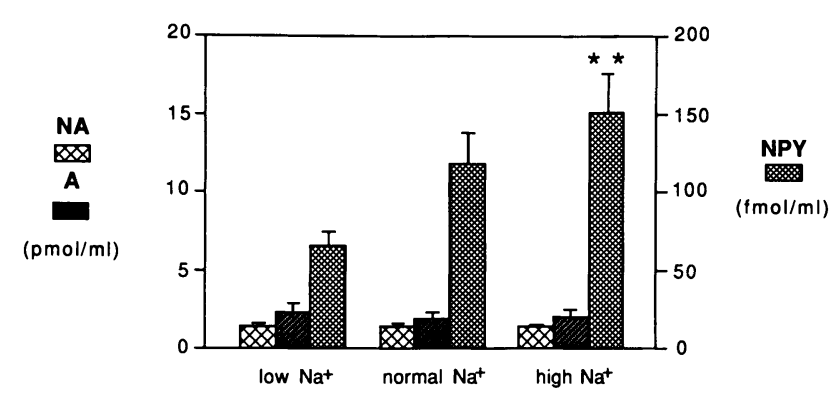

FIGURE 1. Comparison of plasma concentrations of NPY with catecholamines in rats kept on low $(\mathrm{n}=10)$, normal $(\mathrm{n}=12)$, and high $(\mathrm{n}=14)$ sodium diets. Plasma noradrenaline, adrenaline, and NPY concentrations are shown in the left, middle, and right columns, respectively, for the three different sodium intakes. The NPY concentration was significantly higher $(* * \mathrm{P}<0.02)$ in the group receiving a high sodium diet when compared to rats on a low sodium diet (from reference 75 ).

When infused for 30 minutes at a dose lacking any effect on systemic pressure, NPY does not modify heart rate and cardiac output in conscious rats. Furthermore, it does not produce major changes in regional blood flow distribution. ${ }^{68}$ In anesthetized rats infused only briefly with NPY ( 2 minutes), blood flow increased in several tissues (notably the kidney and the heart) in the absence of a generalized effect on hemodynamics. ${ }^{69} \mathrm{~A}$ potentially important function of NPY appears to be an inhibitory action on the response of the cardiac vagus to sympathetic stimulation. ${ }^{70,71}$

A number of interesting findings have been obtained by studying the relationship between blood pressure responsiveness and NPY in states where responses to vasoconstrictor agents are altered. Endotoxemia is one condition in which vascular responsiveness to pressor agonists has been shown to be markedly suppressed, both in hypotensive and nonhypotensive states. ${ }^{72,73}$ It is therefore noteworthy that NPY infused at a nonpressor dose can reverse this abnormality. ${ }^{61}$ It is perhaps through this mechanism that NPY prevents the blood pressure fall induced by endotoxin in rats subjected to adrenal medullectomy. ${ }^{74}$

NPY may also be involved in the modulation of blood pressure responsiveness during changes in sodium balance. ${ }^{75}$ Thus, circulating levels of NPY were higher in rats maintained for 3 weeks on a high sodium intake than in animals kept for the same period on a salt-deficient diet. Intermediate values were obtained in rats fed with a regular sodium intake (Figure 1). It has to be stressed that plasma norepinephrine and epinephrine achieved similar levels in the three different study groups. Sodium loading is known to enhance blood pressure responsiveness to norepinephrine and to favor the development of hypertension. It is therefore conceivable that an excess of sodium influences blood pressure regulation to some extent via an increase in circu- 
lating NPY levels, which in turn potentiate the vasoconstrictor effect of $\alpha$-adrenoceptor stimulation.

Some of the cardiovascular effects of NPY may be related to an action of the peptide on the secretion of hormones physiologically involved in blood pressure control. For instance, NPY suppresses renin release, ${ }^{76,77}$ most likely by inhibiting adenylate cyclase activity in renin-producing cells through a pathway involving the protein Gi. ${ }^{77}$ NPY has also been shown to increase the release of the atrial natriuretic factor; ${ }^{78}$ the significance of this finding is less clear but it could lead to diuresis and natriuresis.

Effects of NPY in Man NPY infused intravenously at a dose that slightly increases blood pressure is well tolerated by normal subjects. ${ }^{\mathbf{7 9}, 80}$ Recently, NPY has been administered directly into a coronary artery of patients with typical angina but no significant abnormality at the arteriogram. ${ }^{81}$ Half of the patients developed a transient myocardial ischemia during infusion of the peptide.

Results obtained in man suggest that NPY is released together with catecholamines when the sympathoadrenal system is activated. This has been shown during physical exercise, ${ }^{82-84}$ in response of the cold pressor test, $^{83}$ as well as during thoracotomy and surgery for cardiopulmonary bypass. ${ }^{85}$ In two studies, ${ }^{82,85}$ there was a significant correlation between plasma levels of NPY and norepinephrine, but not between plasma levels of NPY and epinephrine. This was taken as andication for a release of neural rather than adrenal origin.

\section{CONCLUSIONS}

Interest in the field of research on NPY has been growing rapidly during recent years. This peptide is widely distributed within the central and peripheral nervous system. The property of NPY that seems to be of major physiologic importance is the action on vascular smooth muscle cells. Indeed, NPY can cause blood vessels to constrict through both direct and indirect mechanisms. NPY may therefore be implicated in cardiovascular homeostasis by modulating blood pressure responsiveness to different pressor stimuli. In addition, there is now some evidence suggesting that NPY influences the secretion of hormones known to play a role in body fluid and blood pressure control.

\section{ACKNOWLEDGMENTS}

The authors thank Ms AF Stalé and Mrs A Dinkel for secretarial assistance.

\section{REFERENCES}

1. Tatemoto K, Mutt V: Isolation of two novel candidate hormones using a chemical method for finding naturally occurring polypeptides. Nature 1980;285:417-418.

2. Tatemoto K: Neuropeptide Y: Complete amino-acid sequence of the brain peptide. Proc Natl Acad Sci USA 1982;79:5485-5489.
3. O'Donohue TL, Chronwall BM, Pruss RM, et al: Neuropeptide $Y$ and peptide $Y Y$ neuronal and endocrine systems. Peptides 1985;6:755-768.

4. Gray TS, Morley JE: Neuropeptide Y: Anatomical distribution and possible function in mammalian nervous system. Life Sci 1986;38:389-401.

5. Allen JM, Bloom SR: Neuropeptide Y: A putative neurotransmitter. Neurochem Int 1986;8:13-22.

6. Edvinsson L, Hakanson R, Wahlestedt C, et al: Effects of neuropeptide $\mathrm{Y}$ on the cardiovascular system. TIPS 1987;8:331-335.

7. Allen YS, Adrian TE, Allen JM, et al: Neuropeptide $Y$ distribution in human brain. Science 1983;221:877-879.

8. Everitt B, Hökfelt T, Terenius L, et al: Differential co-existence of neuropeptide Y (NPY)-like immunoreactivity with catecholamines in the central nervous system of the rat. Neuroscience 1984;11:443-462.

9. Fuxe K, Agnati LF, Härfstrand A, et al: Central administration of neuropeptide $Y$ induces hypotension, bradypnea and EEG synchronization in the rat. Acta Physiol Scand 1983;118:189-192.

10. Härfstrand A, Fuxe K, Agnati LF, et al: Studies on neuropeptide $Y$-catecholamine interactions in the hypothalamus and in the forebrain of the male rat. Relationship to neuroendocrine function. Neurochem Int 1986;8:355-376.

11. Agnati LF, Fuxe $K$, Benfenati F, et al: Neuropeptide $Y$ in vitro selectively increased the number of alpha2-adrenergic binding sites in membranes of the medulla oblongata of the rat. Acta Physiol Scand 1985;118:293-295.

12. Martine $M$, Fuxe $K$, Pistritto $G$, et al: Neuropeptide $Y$ enhances the inhibitory effects of clonidine on ${ }^{3} \mathrm{H}$-noradrenaline release in synaptosomes isolated from the medulla oblongata of the male rat. J Neural Transm 1986;67:113-124.

13. Petty MA, Dietrich R, Lang RE: The cardiovascular effects of neuropeptide Y (NPY). Clin Exp Hypertens 1984;6:1889-1892.

14. Vallejo M, Lightman SL: Pressor effect of centrally administered neuropeptide $\mathrm{Y}$ in rats: Role of sympathetic nervous system and vasopressin. Life Sci 1986;38:18591866.

15. Carter DA, Vallejo M, Lightman SL: Cardiovascular effects of neuropeptide $Y$ in the nucleus tractus solitarius of rats: Relationship with noradrenaline and vasopressin. Peptides 1985;6:421-425.

16. Vallejo M, Carter DA, Biswas $S$, et al: Neuropeptide $Y$ alters monoamine turnover in the rat brain. Neurosci Lett 1987;73:155-160.

17. Serfozo P, Bartfai T, Vizi ES: Presynaptic effects of neuropeptide $\mathrm{Y}$ on $\left[{ }^{3} \mathrm{H}\right]$ noradrenaline and $\left[{ }^{3} \mathrm{H}\right]$ acetylcholine release. Regulatory Peptides 1986;16:117-123.

18. MacCarrone C, Jarrott B, Conway EL: Comparison of neuropeptide $Y$ immunoreactivity in hypothalamic and brainstem nuclei of young and mature spontaneously hypertensive and normotensive Wistar-Kyoto rats. Neurosci Lett 1986;68:232-238.

19. Chang RSL, Lotti VJ, Chen TB: Increased neuropeptide $Y$ (NPY) receptor binding in hippocampus and cortex of spontaneous hypertensive $(\mathrm{SH})$ rats compared to 
normotensive (WKY) rats. Neurosci Lett 1986;67: 275-278.

20. Westlind-Danielsson A, Unden A, Abens J, et al: Neuropeptide $\mathrm{Y}$ receptors and the inhibition of adenylate cyclase in the human frontal and temporal cortex. Neurosci Lett 1987;74:237-242.

21. Härfstrand A, Fredholm B, Fuxe K: Inhibitory effects of neuropeptide $Y$ on cyclic AMP accumulation in slices of the nucleus tractus solitarius region of the rat. Neurosci Lett 1987;76:185-190.

22. Uddman R, Ekblad E, Edvinsson L, et al: Neuropeptide $Y$-like immunoreactivity in perivascular nerve fibres of the guinea-pig. Regulatory Peptides 1985;10:243-257.

23. Allen JM, Polak JM, Rodrigo J, et al: Localisation of neuropeptide $Y$ in nerves of the rat cardiovascular system and the effect of 6-hydroxydopamine. Cardiovasc Res 1985;19:570-577.

24. Lundberg JM, Saria A, Franco-Cereceda A, et al: Differential effects of reserpine and 6-hydroxydopamine on neuropeptide $\mathrm{Y}$ (NPY) and noradrenaline in peripheral neurons. Naunyn Schmiedeberg's Arch Pharmacol 1985;328:331-340.

25. Morris JL, Murphy R, Furness JB, et al: Partial depletion of neuropeptide $Y$ from noradrenergic perivascular and cardiac axons by 6-hydroxydopamine and reserpine. Regulatory Peptides 1986;13:147-162.

26. Edvinsson L, Ekblad E, Hakanson R, et al: Neuropeptide $Y$ potentiates the effect of various vasoconstrictor agents on rabbit blood vessels. Br J Pharmacol 1984;83:519525.

27. Aizawa $Y$, Murata $M$, Hayashi $M$, et al: Vasoconstrictor effect of neuropeptide $Y$ (NPY) on canine coronary artery. Jpn Circ J 1985;49:584-588.

28. Wahlestedt C, Edvinsson L, Ekblad E, et al: Neuropeptide $\mathrm{Y}$ potentiates noradrenaline-evoked vasoconstriction: Mode of action. J Pharmacol Exp Ther $1985 ; 234: 735-741$.

29. Hanko JH, Toernebrandt K, Hardebo JE, et al: Neuropeptide $Y$ induces and modulates vasoconstriction in intracranial and peripheral vessels of animals and man. J Auton Pharmacol 1986;6:117-124.

30. Lundberg JM, Tatemoto K: Pancreatic polypeptide family (APP, BPP, NPY and PYY) in relation to sympathetic vasoconstriction resistant to alpha-adrenoceptor blockade. Acta Physiol Scand 1982;116:393-402.

31. Edvinsson L, Emson L, McCulloch J, et al: Neuropeptide Y: Cerebrovascular innervation and vasomotor effect in the cat. Neurosci Lett 1983;43:79-84.

32. Han C, Abel PW: Neuropeptide $Y$ potentiates contraction and inhibits relaxation of rabbit coronary arteries. J Cardiovasc Pharmacol 1987;9:675-681.

33. Neild TO: Actions of neuropeptide $Y$ on innervated and denervated rat tail arteries. J Physiol 1987;386:19-30.

34. Casteels R, Kitamura K, Kuriyama H, et al: Excitationcontraction coupling in the smooth muscle cells of the rabbit main pulmonary artery. J Physiol 1977;271: 63-79.

35. Mulvany MJ, Nilsson H, Flatman JA: Role of membrane potential in the responses of rat small mesenteric arteries to exogenous noradrenaline stimulation. J Physiol 1982;332:363-373.
36. Fredholm BB, Jansen I, Edvinsson L: Neuropeptide $Y$ is a potent inhibitor of cyclic AMP accumulation in feline cerebral blood vessels. Acta Physiol Scand 1985;124:467-469.

37. Daly RN, Hieble JP: Neuropeptide Y modulates adrenergic neurotransmission by an endothelium dependent mechanism. Eur J Pharmacol 1987;138:445-446.

38. Lundberg JM, Pernow J, Tatemoto K, et al: Pre- and postjunctional effects of NPY on sympathetic control of rat femoral artery. Acta Physiol Scand 1985;123:511-513.

39. Lundberg JM, Anggard A, Pernow J, et al: Neuropeptide $\mathrm{Y}-$, substance $\mathrm{P}$ - and VIP-immunoreactive nerves in cat spleen in relation to autonomic vascular and volume control. Cell Tissue Res 1985;239:9-18.

40. Fried G, Terenius L, Brodin E, et al: Neuropeptide $Y$, enkephalin and noradrenaline coexist in sympathetic neurons innervating the bovine spleen. Cell Tissue Res 1986;243:495-508.

41. Corder R, Lowry PJ, Withrington PG: The actions of the peptides, neuropeptide $Y$ and peptide $Y Y$, on the vascular and capsular smooth muscle of the isolated, blood-perfused spleen of the dog. Br J Pharmacol 1987;90:785-790.

42. Lundberg JM, Anggard A, Theodorsson-Norheim E, et al: Guanethidine-sensitive release of neuropeptide $Y$ immunoreactivity in the cat spleen by sympathetic nerve stimulation. Neurosci Lett 1984;52:175-180.

43. Gu J, Polak JM, Allen JM, et al: High concentrations of a novel peptide, neuropeptide $Y$, in the innervation of mouse and rat heart. J Histochem Cytochem 1984;32:467-472.

44. Allen JM, Bircham PM, Edwards AV, et al: Neuropeptide Y (NPY) reduces myocardial perfusion and inhibits the force of contraction of the isolated perfused rabbit heart. Regulatory Peptides 1983;6:247-253.

45. Lundberg JM, Hua SY, Franco-Cereceda A: Effects of neuropeptide $Y$ (NPY) on mechanical activity and neurotransmission in the heart, vas deferens and urinary bladder of the guinea-pig. Acta Physiol Scand 1984;121:325-332.

46. Allen JM, Gjörstrup P, Björkman JA, et al: Studies on cardiac distribution and function of neuropeptide $\mathrm{Y}$. Acta Physiol Scand 1986;126:405-411.

47. Wahlestedt C, Wohlfart B, Hakanson R: Effects of neuropeptide $Y$ (NPY) on isolated guinea-pig heart. Acta Physiol Scand 1987;129:459-463.

48. Rioux F, Bachelard H, Martel JC, et al: The vasoconstrictor effect of neuropeptide $Y$ and related peptides in the guinea-pig isolated heart. Peptides 1986;7:27-31.

49. Kassis S, Olasmaa M, Terenius L, et al: Neuropeptide $Y$ inhibits cardiac adenylate cyclase through a pertussis toxin-sensitive G protein. J Biol Chem 1987;262:34293431.

50. Varndell IM, Polak JM, Allen JM, et al: Neuropeptide tyrosine (NPY) immunoreactivity in norepinephrinecontaining cells and nerves of the mammalian adrenal gland. Endocrinology 1984;114:1460-1462.

51. Majane EA, Alho $H$, Kataoka $Y$, et al: Neuropeptide $Y$ in bovine adrenal glands and characterization. Endocrinology 1986;117:1162-1168. 
52. Lundberg JM, Hökfelt $T$, Hemsen A, et al: Neuropeptide $Y$ immunoreactivity in adrenaline cells of adrenal medulla and in tumours and plasma of pheochromocytoma patients. Regulatory Peptides 1986;13:169-182.

53. Pruss RM, Mezey E, Forman DS, et al: Enkephalin and neuropeptide Y: Two colocalized neuropeptides are independently regulated in primary cultures of bovine chromaffin cells. Neuropeptides 1986;7:315-327.

54. Adrian TE, Allen JM, Terenghi G, et al: Neuropeptide $Y$ in pheochromocytomas and ganglioneuroblastomas. Lancet 1983;2:540-542.

55. Corder R, Emson PC, Lowry PJ: Purification and characterization of human neuropeptide $Y$ from adrenalmedullary pheochromocytoma tissue. Biochem J 1984;219:699-706.

56. Corder R, Lowry PJ, Emson PC, et al: Chromatographic characterisation of the circulating neuropeptide $Y$ immunoreactivity from patients with pheochromocytoma. Regulatory Peptides 1985;10:91-97.

57. Corder R, Shapiro B, Lowry PJ, et al: Relationship between tumour and plasma concentrations of neuropeptide $\mathrm{Y}$ in patients with adrenal medullary pheochromocytoma. J Hypertension 1986;4(Suppl 6):193-195.

58. Lundberg JM, Fried G, Pernow J, et al: Co-release of neuropeptide $Y$ and catecholamines upon adrenal activation in the cat. Acta Physiol Scand 1986;126:231238.

59. Morris MJ, Kapoor V, Chalmers J: Plasma neuropeptide $Y$ concentration is increased after hemorrhage in conscious rats: Relative contributions of sympathetic nerves and the adrenal medulla. J Cardiovasc Pharmacol 1987;9:541-545.

60. Dahlöf C, Dahlöf P, Lundberg JM: Neuropeptide $Y$ (NPY): Enhancement of blood pressure increase upon alpha-adrenoceptor activation and direct pressor effects in pithed rats. Eur J Pharmacol 1985;109:289-292.

61. Evéquoz D, Waeber B, Corder R, et al: Markedly reduced blood pressure responsiveness in endotoxemic rats; reversal by neuropeptide Y. Life Sci 1987 (In Press).

62. Mabe Y, Tatemoto K, Huidobro-Toro JP: Neuropeptide $\mathrm{Y}$-induced pressor responses: Activation of a nonadrenergic mechanism, potentiation by reserpine and blockade by nifedipine. Eur J Pharmacol 1985;116: 33-39.

63. Corder R, Lowry PJ, Wilkinson SJ, et al: Comparison of the haemodynamic actions of neuropeptide $Y$, angiotensin II and noradrenaline in anaesthetised cats. Eur J Pharmacol 1986;121:25-30.

64. Zukowska-Grojec Z, Haass M, Bayorth MA: Neuropeptide $Y$ and peptide $Y Y$ mediate non-adrenergic vasoconstriction and modulate sympathetic responses in rats. Regulatory Peptides 1986;15:99-110.

65. Allen JM, Bircham PMM, Bloom SR, et al: Release of neuropeptide $Y$ in response to splanchnic nerve stimulation in the conscious calf. J Physiol 1984;357:401408.

66. Dahlöf C, Dahlöf $P$, Lundberg JM: Alpha2-adrenoceptor-mediated inhibition of nerve stimulation-evoked release of neuropeptide Y (NPY)-like immunoreactivity in the pithed guinea-pig. Eur J Pharmacol 1986;131:279283.
67. Corder R, Waeber B, Evéquoz D, et al: Effect of ganglion blockade with pentolinium on circulating neuropeptide Y levels in conscious rats. J Cardiovasc Pharmacol 1988 (In press).

68. Aubert JF, Burnier M, Waeber B, et al: Effects of a nonpressor dose of neuropeptide $Y$ on cardiac output, regional blood flow distribution and plasma renin, vasopressin and catecholamine levels. (Submitted for publication).

69. Huffman L, Hedge GA: Neuropeptide control of thyroid blood flow and hormone secretion in the rat. Life Sci 1986;39:2143-2150.

70. Potter EK: Prolonged non-adrenergic inhibition of cardiac vagal action following sympathetic stimulation: Neuromodulation by neuropeptide Y? Neurosci Lett 1985;54:117-121.

71. Potter EK: Cardiac vagal action and plasma levels of neuropeptide $\mathrm{Y}$ following intravenous injection in the dog. Neurosci Lett 1987;77:243-247.

72. Schaller MD, Waeber B, Nussberger J, et al: Angiotensin II, vasopressin, and sympathetic activity in conscious rats with endotoxemia. Am J Physiol 1985;249:H1086H1092.

73. Burnier M, Waeber B, Aubert JF, et al: Vascular and humoral effects of non-hypotensive endotoxemia in conscious rats: Role of prostaglandins. Am J Physiol, 1988 (In press).

74. Evéquoz D, Waeber B, Aubert JF, et al: Neuropeptide $Y$ prevents the blood pressure fall induced by endotoxin in conscious rats with adrenal medullectomy. Circ Res (In press)

75. Waeber B, Corder R, Aubert JF, et al: Influence of sodium intake on circulating levels of neuropeptide $\mathrm{Y}$ in normotensive rats. Life Sci (In press)

76. Pfister A, Waeber B, Nussberger J, et al: Neuropeptide $Y$ normalizes renin secretion in adrenalectomized rats without changing blood pressure. Life Sci 1986;39:2161-2167.

77. Hackenthal E, Aktories K, Jakobs KH, et al: Neuropeptide $\mathrm{Y}$ inhibits renin release by a pertussis toxinsensitive mechanism. Am J Physiol 1987;552:F543F550.

78. Baranowska B, Gutkowska J, Lemire A, et al: Opposite effects of neuropeptide Y (NPY) and polypeptide YY (PYY) on plasma immunoreactive atrial natriuretic factor (IR-ANF) in rats. Biochem Biophys Res Commun 1987;145:680-685.

79. Allen JM, Bloom SR: NPY infusion elevated blood pressure. Reg Peptides 1985;13:89.

80. Pernow J, Lundberg JM, Kaijser L: Vasoconstrictor effects in vivo and plasma disappearance rate of neuropeptide $Y$ in man. Life Sci 1987;40:47-54.

81. Clarke JG, Davies GJ, Kerwin R, et al: Coronary artery infusion of neuropeptide $\mathrm{Y}$ in patients with angina pectoris. Lancet 1987;1:1057-1059.

82. Lundberg JM, Martinsson A, Hemsen A, et al: Co-release of neuropeptide $\mathrm{Y}$ and catecholamines during physical exercise in man. Biochem Biophys Res Commun 1985;133:30-36.

83. Morris $M J$, Russell AE, Kapoor $\mathrm{V}$, et al: Increases in plasma neuropeptide $Y$ concentrations during sympa- 
thetic activation in man. J Auton Nervous System 1986;17:143-149.

84. Pernow J, Lundberg JM, Kaijser L, et al: Plasma neuropeptide $Y$ like immunoreactivity and catecholamines during various degrees of sympathetic activation in man. Clin Physiol 1986;6:561-578.
85. Lundberg JM, Torssell L, Sollevi A, et al: Neuropeptide $Y$ and sympathetic vascular control in man. Regulatory Peptides 1985; 13:41-52. 